Wydziat Nauk Spolecznych, Instytut Pedagogiki

Uniwersytet Gdański

\title{
Instytucjonalny i organizacyjny rozwój średnich szkół ogólnokształcących w województwie gdańskim po II wojnie światowej (1945-1948)
}

\begin{abstract}
Institutional and organisational development of secondary education in the Gdańsk region after the Second World War (1945-1948)

After World War II, high schools in the Gdansk region had to be built virtually from scratch. However, it is evident there were some major differences between the new and old districts, where the schools' tasks went beyond teaching. Their role was to integrate local communities and give them a sense of stability. The former secondary school districts began their activities on the basis of pre-war organisational structures, and were established very quickly, almost immediately after the war ended. However, the network of grammar schools in new counties formed much more slowly, although in the 1945/46 school year there was already a secondary school in each county town. The intensity of the development of secondary schools can be shown in numbers. In the 1944/1945 school year, 14 secondary schools were established, and a year later there were already 28 . With the development of institutional schools, their organisational development followed. Within a year, the number of students nearly trebled. Quickly, though not as strongly, there was an increase in the number of teachers. The major breakthrough for these institutions was 1948, in which, by decision of the school and party authorities, Poland experienced the reorganisation of general school education.
\end{abstract}

Keywords: grammar schools, secondary schools, school network, the post-war period, Gdańsk county, students, teachers

Rozwój średniego szkolnictwa ogólnokształcącego w województwie gdańskim w okresie powojennym warunkowały ogólnopolskie koncepcje działalności szkół poszczególnych szczebli wypracowane przez rząd w odniesieniu do warunków politycznych, społecznych i ekonomicznych panujących w Polsce po 1945 r. Ogólny zarys nowych celów i zadań polityki oświatowej zawarto już w Manifeście PKWN z 22 lipca 1944 r. Uszczegółowienie głównych kierunków nowej polityki oświatowej nastąpiło na Ogólnopolskim Zjeździe Oświatowym w Łodzi, który odbył się w dniach 18-22 czerwca 
1945 r. W jego rezolucji końcowej wskazano m.in. na powszechność, bezpłatność i jednolitość kształcenia na wszystkich poziomach systemu oświaty, decentralizację sieci szkół średnich oraz budowę 8-letniej i 8-klasowej obowiązkowej oraz jednolitej pod względem programowym i organizacyjnym szkoły na wsi i w mieście ${ }^{1}$. Uznając poniekąd dorobek polskiej szkoły, władze zapoczątkowały działania zmierzające do ukształtowania jej nowego oblicza ideowego. Ustępstwem ze strony Ministerstwa było pozostawienie religii w szkole ${ }^{2}$. W roku szkolnym 1944/45 działalność szkolnictwa średniego ogólnokształcącego oparto na zapisach ustawy z 11 marca 1932 r., która zakładała 2-stopniową organizację szkoły średniej ogólnokształcącej. Tworzyły ją 4-letnie jednolite pod względem programowym gimnazja i 2-letnie licea zróżnicowane programowo ${ }^{3}$. Jednakże już w lipcu 1945 r. na podstawie Instrukcji w sprawie organizacji roku szkolnego 1945/46 w średnich szkołach ogólnokształcących wprowadzono pewne zmiany w zakresie form kształcenia. Klasie pierwszej gimnazjalnej nadano charakter klasy wstępnej wyrównawczej, a absolwentów klasy VII szkoły powszechnej przyjmowano do klasy drugiej. Powołano także skrócone dwuletnie szkoły gimnazjalne o ustroju semestralnym dla młodzieży opóźnionej wiekiem oraz gimnazja dla dorosłych dzienne i wieczorowe, również o ustroju semestralnym. Wprowadzono także zmiany w liceach ogólnokształcących, likwidując wydziały klasyczne. Pozostawiono natomiast wydziały: humanistyczny, matematyczno-fizyczny i przyrodniczy. Organizacja liceów ogólnokształcących przewidywała ponadto skrócone 3-letnie licea o ustroju semestralnym dla starszej młodzieży oraz 2-letnie licea dla dorosłych ${ }^{4}$.

W roku szkolnym 1946/47 dokonano istotnych zmian w strukturze gimnazjów. Likwidując klasę pierwszą, przekształcono je w szkoły 3-letnie. Przejściowo jednak zezwolono na tworzenie (tylko w roku szkolnym 1946/47) przy gimnazjach klas wstępnych wyrównawczych dla absolwentów klas VI szkół podstawowych niżej zorganizowanych. Przewidziano również tworzenie nowych skróconych form kształcenia o ustroju semestralnym. Były to 2-letnie szkoły gimnazjalne organizowane jako podbudowa liceów pedagogicznych lub szkół zawodowych stopnia licealnego oraz 3-letnie pełne szkoły średnie bez podziału na gimnazjum i liceum ${ }^{5}$. W następnym roku szkolnym organizacja gimnazjów przybrała jeszcze inną formę. W ich strukturze wyróżniono klasę wstępną, drugą i trzecią. Ustrój liceów ogólnokształcących pozostał bez zmian ${ }^{6}$.

\footnotetext{
${ }^{1}$ Dokumenty naszej tradycji. Manifest Polskiego Komitetu Wyzwolenia Narodowego, Lublin 1984, s. 45; Ogólnopolski Zjazd Oświatowy w Łodzi 18-22 czerwca 1945, Ministerstwo Oświaty, Warszawa 1945, s. 247.

2 Por.: H. Konopka, Religia w szkołach Polski Ludowej, Białystok 1997, s. 13-30.

${ }_{3}$ M. Pęcherski, M Świątek, Organizacja oświaty w Polsce w latach 1917-1977. Podstawowe akty prawne, Warszawa 1978, s. 195.

${ }^{4}$ Dz. Urz. Min. Oświaty 1945, Nr 2, poz. 62, Instrukcja Ministerstwa Oświaty z dnia 16 lipca 1945 roku W sprawie organizacji roku szkolnego 1945/46 w średnich szkołach ogólnokształcących.

5 Archiwum Państwowe w Gdańsku (dalej: APG) Kuratorium Okręgu Szkolnego Gdańskiego (dalej: KOSG), 1945-1991, sygn. 1178/20, Instrukcja z dnia 15 maja 1946 roku w sprawie organizacji szkolnictwa średniego ogólnokształcącego w roku szkolnym 1946/47, k. 53-54.

${ }^{6}$ W. Ozga, Organizacja szkolnictwa w Polsce Ludowej, Warszawa 1960, s. 119.
} 
Nie bez znaczenia dla rozwoju średniego szkolnictwa ogólnokształcącego w województwie gdańskim były też uwarunkowania regionalne związane ze specyfiką tego obszaru. Na plan pierwszy wysuwały się tu specyficzne warunki społeczno-demograficzne, w tym ruchy migracyjne, które kształtowały m.in. powojenne podziały administracyjne. Należy tu podkreślić, że województwo gdańskie było wyjątkiem pod względem administracyjnym z uwagi na różnorodność pochodzenia jego części składowych. Łączyło ziemie należące przed II wojną światową do czterech układów administracyjno-politycznych: województwa pomorskiego Rzeczypospolitej Polskiej, Wolnego Miasta Gdańska, Prus Wschodnich i rejencji koszalińskiej Pomorza Zachodniego. Przez wiele lat zaznaczał się tu podział na tzw. powiaty dawne i powiaty nowe ${ }^{7}$. W okresie powojennym na ziemiach dawnych przeważała zdecydowanie rodzima ludność polska, a zmiany społeczne dokonywały się tu pod znakiem jej powrotu w strony rodzinne. Liczba ludności napływowej w tym pasie powiatów była niewielka. Zatem przemiany koncentrowały się na przebudowie struktur oświatowych, a nie na tworzeniu ich od podstaw. Na ziemiach nowych dominowały odmienne zjawiska. Tu liczba polskiej ludności autochtonicznej była stosunkowo nieznaczna, a prowadzone wobec niej działania weryfikacyjne, repolonizacyjne i rehabilitacyjne przyczyniały się do dezintegracji tej grupy ${ }^{8}$. Tworzenie szkół było jednym z elementów stymulujących proces zasiedlania i zagospodarowywania tych terenów, jak również przejawem normalizacji życia społecznego. Władze postawiły tu przed oświatą cele wykraczające poza dydaktykę i wychowanie. Szkoła miała wpływać na tworzenie się jednolitego społeczeństwa, podniesienie poziomu kulturalnego regionu, zająć się również repolonizacją i polonizacją ludności rodzimej, a także integrować przejęte tereny z pozostałą częścią Polski ${ }^{9}$. Zakładanie szkół zależne było od tempa akcji osiedleńczej. Często działo się tak, że powoływano szkołę, gdy posiadano budynek, a do pracy mógł przystąpić chociaż jeden nauczyciel ${ }^{10}$. Wielu mieszkańców przybywających na te tereny swoje osiedlenie warunkowało uruchomieniem szkoły średniej. Na takie zjawisko zwracał między innymi uwagę dyrektor Państwowego Gimnazjum i Liceum w Malborku: Wśród ludności budzi się coraz żywiej zainteresowanie, czy w mieście będzie gimnazjum i liceum. Wielu spośród inteligencji uzależnia swoje osiedlenie się w Malborku od tego faktu $[\ldots]^{11}$.

\footnotetext{
${ }^{7}$ Powiaty dawne: kartuski, wejherowski, starogardzki, kościerski, tczewski i miasto Gdynia Natomiast powiaty nowe to: elbląski (miasto Elbląg i powiat), kwidzyński, lęborski, malborski, sztumski oraz powiat gdański utworzony z byłego Wolnego Miasta Gdańsk. Zob. G. Baziur, Armia Czerwona na Pomorzu Gdańskim, Warszawa 2003, s. 9.; J. Siekierzyński, Tworzenie administracji państwowej w województwie gdańskim (1945-1950), Gdańsk 1978, s. 14.

${ }^{8}$ O. Sochacki, Przemiany wsi nadmorskich $w$ woj. gdańskim $w$ 30-leciu PRL, w: Przemiany społeczne w regionie gdańskim w powojennym 30-leciu, pod red. K. Podoskiego, Gdańsk 1977, s. $202-203$.

9 Cz. Osękowski, Społeczeństwo Polski zachodniej i pótnocnej w latach 1945-1956, Zielona Góra 1994, S. $195-198$.

${ }^{10}$ B. Potyrała, W. Szlufik, Szkolnictwo ogólnokształcace na Ziemiach Zachodnich i Pólnocnych w latach 1945-1970, Wrocław 1972, s.120-121.

11 APG, KOSG 1945-1991, sygn.. 1178/18, Do Kuratorium Okręgu Szkolnego Gdańskiego, Sprawozdanie dyrektora Państwowego Gimnazjum i Liceum w Malborku, k. 366.
} 
W województwie gdańskim do organizacji szkolnictwa średniego ogólnokształcącego przystąpiono praktycznie natychmiast po zakończeniu działań wojennych. Już na początku kwietnia 1945 r. do Gdańska przybyła grupa operacyjna Ministerstwa Oświaty. Kierował nią dr Stanisław Turski. Pozostali jej członkowie to: dr Kazimierz. Kubik, dr Marian Pelczar, dr Jan Szwarc, mgr Jan Kilarski, inż. Kazimierz Kopecki, inż. Franciszek Otto i Stanisław Szymański. Organizację szkolnictwa powszechnego i średniego powierzono dr. Kazimierzowi Kubikowi. 16 kwietnia dotarła do Gdańska druga grupa operacyjna administracji szkolnej, którą kierował mgr Jan Młynarczyk. Zajęła się ona organizacją Kuratorium Okręgu Szkolnego Gdańskiego, którego siedzibą był początkowo Sopot. Dokonano podziału okręgu gdańskiego na dwa obwody: miejski i powiatowy oraz zajęto się organizacją szkolnictwa w powiatach. Tu podstawę administracji szkolnej stanowiły inspektoraty ${ }^{12}$.

Wstępne prace organizacyjne w szkolnictwie średnim ogólnokształcącym polegały na wyszukiwaniu, porządkowaniu i zabezpieczeniu budynków szkolnych, przygotowaniu ich do działalności dydaktycznej, kompletowaniu kadry nauczycielskiej oraz zapisach młodzieży do szkół. Były to zadania niezwykle trudne do wykonania. Zabudowania szkolne były bardzo mocno zniszczone. W czasie wojny bardzo często stacjonowało w nich wojsko niemieckie, a po przejściu frontu przejęła je armia sowiecka. Tak opisuje stan budynków przejętych na cele Państwowego Gimnazjum i Liceum w GdańskuWrzeszczu jej pierwszy dyrektor Henryk Ryduch: $W$ dniu 10 kwietnia objąłem niemieckie liceum we Wrzeszczu przy Taubenweg 3 [...]. Stan budynków i inwentarza był w opłakanym stanie. Wojsko niemieckie i rosyjskie przechodziło kilkakrotnie przez tereny i budynki używajac ich jako kwater dla ludzi, bydła i koni. Podwórze było założone różnym sprzętem wojskowym, między którym znajdowaty się tawki szkolne, tablice ksią̇ki. [...] Budynki ucierpiały wskutek działań wojennych, a jeden został poważnie uszkodzony przez obstrzat artylerii. [...] Szyby wszystkie byty wybite. Szkło leżało wszędzie $e^{13}$.

W takich warunkach przygotowywano się do uruchomienia innych gimnazjów i liceów. Jednakże ze względu na trudności związane z niewielkim naborem uczniów nie wszystkie od razu rozpoczęły działalność edukacyjną. Brak chętnych wypływał przede wszystkim z niewielkiej jeszcze liczby ludności polskiej. Akcja osiedleńcza na tych terenach zaczęła rozwijać się na przełomie czerwca i lipca 1945 r., kiedy dotarł pierwszy transport osadników z Łodzi. Znacząca, bo ponad stutysięczna, grupa przesiedleńców i repatriantów przybyła na teren województwa gdańskiego dopiero w sierpniu 1945 r. ${ }^{14}$ Ponadto pionierzy przyjeżdżali najczęściej na Ziemie Odzyskane bez rodzin, gdyż sytuacja gospodarcza, społeczna i polityczna nie gwarantowała pewnego jutra. W pierwszych miesiącach po zakończeniu wojny ujawniały się też liczne problemy związane z zasie-

\footnotetext{
${ }^{12}$ K. Kubik, Szkolnictwo województwa gdańskiego w okresie Polski Ludowej (1945-1963), „Gdańskie Zeszyty Humanistyczne” 1964, nr 12, s. 73-74.

13 APG, KOSG 1945-1991, sygn.. 1178/18, Sprawozdanie z dotychczasowych prac wykonanych w Państwowym Gimnazjum i Liceum we Wrzeszczu, k. 359.

${ }^{14}$ APG, Urząd Wojewódzki w Gdańsku (dalej: UWG) 1945-1954, sygn. 1164/354, Sprawozdanie z akcji osiedleńczej z dn. 27.06.1945 r., k. 3; ibidem, Sprawozdanie miesięczne referatu akcji osiedleńczej za miesiąc lipiec 1945 r., k. 16-18.
} 
dlaniem i zagospodarowywaniem tych ziem. Praktycznie nie działała polska administracja państwowa, skutecznie paraliżowana przez radziecką komendanturę wojenną. Duże trudności występowały w zakresie bezpieczeństwa publicznego. Na porządku dziennym były napady, gwałty, grabieże z bronią w ręku dokonywane na osadnikach przez żołnierzy radzieckich. Odnotowywano także przypadki usuwania Polaków z mieszkań czy gospodarstw. Groźnym zjawiskiem była jawna współpraca Armii Czerwonej z Niemcami. $\mathrm{Ci}$, mając poparcie radzieckiej komendantury, stawiali opór władzom polskim, odmawiając wykonywania prac przy odgruzowywaniu miasta, bądź dokonując sabotażu gospodarczego. Zanotowano również próby tworzenia przez Niemców tajnych organizacji. Na przykład w Lęborku te działania wspierane były przez Rosjan, którzy pod przykrywką utworzonej przez siebie instytucji „Ortsbauernführers” zezwalali na tajne spotkania Niemców ${ }^{15}$. Ponadto tereny te obok ludności zamierzającej osiedlić się tu na stałe, przyciągały rzesze osób chcących szybko i łatwo się wzbogacić, tzw. szabrowników. Dokonywali oni kradzieży nie tylko porzuconego mienia poniemieckiego ${ }^{16}$, ale również $\mathrm{w}$ celach rabunkowych napadano na urzędy państwowe czy sklepy. Szczególnie niebezpieczne były tereny powiatów nowych. Pełnomocnik Rządu RP na obwód Słupsk w swoim sprawozdaniu zapisał: Na terenie powiatu trafiaja się wypadki, że uzbrojone bandy przyjeżḋaja samochodami osobowymi, zachodza do większych sklepów i sterroryzowawszy właścicieli zabieraja co im się podoba i odjeżdzają sobie dalej w nieznane ${ }^{17}$.

Pierwsze średnie szkoły ogólnokształcące działalność edukacyjną zainicjowały w maju 1945 r. ${ }^{18}$ Były to placówki rozmieszczone w Gdańsku, Gdyni, a także w większości miast powiatowych ziem dawnych województwa gdańskiego. Do końca czerwca 1945 r. powołano 12 tego typu placówek ${ }^{19}$. Należy też dodać, że obok szkół państwowych działały również szkoły prywatne. Były to: Gimnazjum i Liceum Żeńskie s.s. Urszulanek w Gdyni oraz Gimnazjum i Liceum Męskie o.o. Jezuitów w Gdyni-Orłowie ${ }^{20}$.

${ }_{15}$ Zob. E. Gorloff, Trudności readaptacyjne dzieci i młodziė̇y szkolnej województwa gdańskiego $w$ warunkach migracji powojennych (studium przypadku), w: Opieka i wychowanie - tradycja i problemy wspótczesne, red. D. Apanel, Kraków 2009, s 89-91.

${ }^{16}$ Fragment sprawozdania Powiatowej Komendy Milicji Obywatelskiej: Przekazano władzom polskim, między innymi blok zabudowań przy ul. Roli-Żymierskiego po bytej niemieckiej „Hochschule für Lehrerbildung. Ów kompleks gmachów, wielomilionowej przedwojennej wartości, obejmuje w swoim składzie najpiękniejsza w Polsce salę teatralno-koncertowa. [....] W ciagu ostatnich dni wyszabrowano szereg pięknych żyrandoli o oryginalnej konstrukcji, klosze do tych żyrandoli, zamki, wyłaczniki i instalacje elektryczna, tablice rozdzielcze, klamki, części instalacji dźwigów elektrycznych, rozmaite narzędzia itp. APG o/Gdynia, Starostwo Powiatowe i Powiatowa Rada Narodowa (dalej: SP i PRN) w Lęborku 1945-1950, sygn. 27, Pismo Powiatowej Komendy Milicji Obywatelskiej Wydział Śledczy w Lęborku,

17 APG, UWG 1945-1954, sygn. 1164/73, Sprawozdanie sytuacyjne za miesiąc luty 1946 r., Pełnomocnik Rządu RP na obwód Słupsk, k. 18.

18 Prezentowane badania obejmują rozwój szkolnictwa średniego ogólnokształcącego dla młodzieży.

${ }^{19}$ W roku szkolnym 1944/45 w województwie gdańskim funkcjonowały licea i gimnazja ogólnokształcące w: Gdańsku (3 placówki), Gdyni (3 placówki), Kartuzach, Kościerzynie, Pucku, Starogardzie, Tczewie oraz Wejherowie. APG, KOSG 1945-1991, sygn.. 1178/ 130, Formularze sprawozdawczo-statystyczne za rok 1945/46 k. 3-197.

${ }^{20}$ APG, KOSG 1945-1991, sygn. 1178/130, Formularz sprawozdawczo-statystyczny za rok szkolny 1945/46, k. 119, 125. 
Z początkiem roku szkolnego 1945/1946 sieć średnich szkół ogólnokształcących znacznie się rozwinęła. Tego typu placówki udało się uruchomić również w powiatach nowych. W województwie gdańskim funkcjonowało wówczas 25 średnich szkół ogólnokształcących dla młodzieży, a w trakcie roku szkolnego uruchomiono jeszcze trzy ${ }^{21}$. Należy zaznaczyć, że w liczbie tych 28 szkół 5 było placówkami niepublicznymi. Do wspomnianego już PGiL s.s. Urszulanek i PGiL o.o. Jezuitów dołączyło Prywatne Żeńskie Gimnazjum s.s. Zmartwychwstania Pańskiego w Wejherowie oraz Prywatne Gimnazjum i Liceum Koedukacyjne Stolicy Biskupiej w Pelplinie. W Gdyni Komitet Powiatowy OMTUR powołał Społeczne Gimnazjum i Liceum OMTUR ${ }^{22}$. Ponadto, jako jedyne tego typu w województwie, przy Państwowym Liceum Pedagogicznym w Wejherowie działało gimnazjum ogólnokształcące przygotowujące kandydatów do tegoż liceum ${ }^{23}$.

W roku szkolnym 1946/47 liczba i sieć średnich szkół ogólnokształcących uległa zmianie. Wpłynęły na to przede wszystkim przekształcenia administracyjne województwa gdańskiego. Jak już wspomniano w czerwcu 1946 r. zostało ono pomniejszone o cztery powiaty (Bytów, Miastko, Sławno, Słupsk), które przyłączono do nowo utworzonego województwa szczecińskiego ${ }^{24}$. Tym samym szkoły funkcjonujące w ramach tych jednostek znalazły się w obszarze działania kuratorium szczecińskiego. Ponadto w Gdańsku - Nowym Porcie powołano do życia Państwowe Gimnazjum i Liceum im. Obrońców Westerplatte, które swoją siedzibę znalazło przy ul. Wyzwolenia $8^{25}$.

Również następny rok szkolny przyniósł reorganizację w sieci szkół średnich ogólnokształcących. Zmiany, które wówczas nastąpiły, zdają się być ukierunkowane założeniami „nowej polityki oświatowej” prowadzonej od marca 1947 r. przez ministra Stanisława Skrzeszewskiego, która miała na celu m.in. likwidację reakcyjnych wpływów w oświacie oraz uregulowanie i kontrolę funkcjonowania szkolnictwa prywatnego ${ }^{26}$. W tym czasie zostało bowiem zlikwidowane Prywatne Gimnazjum o.o. Jezuitów w Gdyni - Orłowie, a na jego miejsce powołano Społeczne Gimnazjum i Liceum ZNP. Ponadto ze względu na brak środków finansowych Komitet Powiatowy OM TUR wygasił działalność prowadzonego przez siebie gimnazjum i liceum. Ostatecznie w roku szkolnym 1947/48 na terenie gdańskiego kuratorium funkcjonowało 25 średnich szkół ogólnokształcących. Szczegółowo sieć tych placówek ukazuje tabela 1.

\footnotetext{
${ }^{21}$ APG, Komitet Wojewódzki PPR (dalej: KW PPR), sygn. 2259/40, Wykaz obrazujący wzrost ilości szkół, nauczycieli, młodzieży uczącej się za czas od 1 V 1945 r. do 1 V 1946 r., k. 26; ibidem, sygn.. 2259/41, Szkolnictw w okręgu gdańskim, k. 17.

${ }^{22}$ APG, KOSG 1945-1991, sygn. 1178/20, Pismo Ministerstwa Oświaty, Przyznanie uprawnień szkół państwowych szkołom niepaństwowym, k. 64.

${ }^{23}$ APG, KOSG 1945-1991, sygn. 1178/130, Formularz sprawozdawczo-statystyczny za rok szkolny 1945/46, k. 398.

${ }^{24}$ Dz. U. 1946 r. Nr 28, poz. 177.

${ }^{25}$ APG, KOSG 1945-1991, sygn. 1178/130, Formularz sprawozdawczo-statystyczny za rok szkolny 1945/46, k. 441.

${ }^{26}$ L. Szuba, Polityka oświatowa państwa polskiego w latach 1944-1956, Lublin 2002, s. 146.
} 
Tabela 1. Wykaz szkół średnich ogólnokształcących w województwie gdańskim w roku szkolnym $1947 / 48$

\begin{tabular}{|c|c|c|c|}
\hline Lp. & Nazwa szkoły & Miasto & Adres \\
\hline 1. & $\begin{array}{l}\text { Państwowe Gimnazjum i Liceum } \\
\text { im. Kazimierza Jagiellończyka }\end{array}$ & Elbląg & ul. Królewiecka 128 \\
\hline 2. & I Państwowe Gimnazjum i Liceum & Gdańsk & ul. Wały Piastowskie 6 \\
\hline 3. & $\begin{array}{l}\text { II Państwowe Gimnazjum i Liceum } \\
\text { im. Władysława Pniewskiego }\end{array}$ & Gdańsk-Wrzeszcz & ul. Wł. Pniewskiego 3 \\
\hline 4. & III Państwowe Gimnazjum i Liceum & Gdańsk-Wrzeszcz & ul. Topolowa 7 \\
\hline 5. & $\begin{array}{l}\text { IV Państwowe Gimnazjum i Liceum } \\
\text { im. Obrońców Westerplatte }\end{array}$ & Gdańsk-Nowy Port & ul. Wyzwolenia 8 \\
\hline 6. & $\begin{array}{l}\text { V Państwowe Gimnazjum i Liceum } \\
\text { im. Stefana Żeromskiego }\end{array}$ & Gdańsk-Oliwa & ul. Polanki 130 \\
\hline 7. & VI Państwowe Gimnazjum i Liceum & Gdańsk & ul. Siennicka 11 \\
\hline 8. & Państwowe Gimnazjum i Liceum Męskie & Gdynia & $\begin{array}{l}\text { ul. Czerwonych } \\
\text { Kosynierów } 79\end{array}$ \\
\hline 9. & $\begin{array}{l}\text { Państwowe Gimnazjum i Liceum Żeńskie } \\
\text { im. Emilii Plater }\end{array}$ & Gdynia & ul. Czołgistów 46 \\
\hline 10. & $\begin{array}{l}\text { Prywatne Gimnazjum i Liceum } \\
\text { Zgromadzenia S.S. Urszulanek }\end{array}$ & Gdynia & ul. Pomorska 41 \\
\hline 11. & Społeczne Gimnazjum i Liceum ZNP & Gdynia-Orłowo & ul. Gdańska 294 \\
\hline 12. & Państwowe Gimnazjum i Liceum & Gniew & ul. Dybowo 12 \\
\hline 13. & $\begin{array}{l}\text { Państwowe Gimnazjum i Liceum } \\
\text { im. Hieronima Derdowskiego }\end{array}$ & Kartuzy & ul. Klasztorna 3 \\
\hline 14. & $\begin{array}{l}\text { Państwowe Gimnazjum i Liceum } \\
\text { im. Józefa Wybickiego }\end{array}$ & Kościerzyna & ul. Kartuska 2 \\
\hline 15. & Państwowe Gimnazjum i Liceum & Kwidzyn & ul. Konarskiego 10 \\
\hline 16. & $\begin{array}{l}\text { Państwowe Gimnazjum i Liceum } \\
\text { im. Stefana Żeromskiego }\end{array}$ & Lębork & ul. Mechaniczna 6 \\
\hline 17. & $\begin{array}{l}\text { Państwowe Gimnazjum i Liceum } \\
\text { im. Henryka Sienkiewicza }\end{array}$ & Malbork & ul. Komandorska 7 \\
\hline 18. & Prywatne Gimnazjum i Liceum & Pelplin & Pl. Tumski \\
\hline 19. & Państwowe Gimnazjum i Liceum & Puck & ul. Zamkowa 2 \\
\hline 20. & $\begin{array}{l}\text { Państwowe Gimnazjum i Liceum Męskie } \\
\text { im. Bolesława Chrobrego }\end{array}$ & Sopot & $\begin{array}{l}\text { ul. Książąt Pomorskich } \\
16 / 18\end{array}$ \\
\hline 21. & $\begin{array}{l}\text { Państwowe Gimnazjum i Liceum Żeńskie } \\
\text { im. Marii Curie-Skłodowskiej }\end{array}$ & Sopot & $\begin{array}{l}\text { ul. Książąt Pomorskich } \\
16 / 18\end{array}$ \\
\hline
\end{tabular}


cd. tab. 1

\begin{tabular}{|c|l|l|l|}
\hline 22. & $\begin{array}{l}\text { Państwowe Gimnazjum i Liceum } \\
\text { im. Stanisława Staszica }\end{array}$ & Starogard & ul. Hallera 34 \\
\hline 23. & Państwowe Gimnazjum i Liceum & Tczew & ul Stalina 18 \\
\hline 24. & $\begin{array}{l}\text { Państwowe Gimnazjum i Liceum } \\
\text { im. Jana Sobieskiego }\end{array}$ & Wejherowo & ul. Sobieskiego 300 \\
\hline 25. & $\begin{array}{l}\text { Prywatne Gimnazjum i Liceum Żeńskie } \\
\text { Zgromadzenia S.S. Zmartwychwstanek }\end{array}$ & Wejherowo & ul. Klasztorna 9 \\
\hline
\end{tabular}

Źródło: APG, KW PPR, sygn. 2259/41, Wykaz szkół średnich ogólnokształcących na terenie Kuratorium Okręgu Szkolnego Gdańskiego, k. 98.

Wraz z rozwojem instytucjonalnym w województwie gdańskim następował również rozwój organizacyjny średniego szkolnictwa ogólnokształcącego. W roku szkolnym 1945/1946 na 28 placówek 10 oferowało kształcenie jedynie na poziomie gimnazjalnym ${ }^{27}$. Dwa lata później w organizacji tych szkół zauważyć można wyraźne zmiany, gdyż już wszystkie placówki prowadziły zarówno klasy gimnazjalne, jak i licealne.

Z roku na rok w gimnazjach i liceach wzrastała też liczba oddziałów i uczniów. Zgodnie z zaleceniami Ministerstwa Oświaty w miarę możliwości i potrzeb realizowały one naukę zarówno w tzw. ciągach normalnych, jaki i skróconych - semestralnych dla młodzieży przerośniętej wiekowo. Na przykład w roku szkolnym 1946/47 we wszystkich gimnazjach uruchomiono ciągi dla wieku normalnego, a w 23 placówkach ciągi dla uczniów opóźnionych wiekowo. W tym samym czasie w 13 liceach młodzież mogła podejmować naukę zarówno w trybie normalnym, jak i semestralnym ${ }^{28}$.

Jak już wspomniano w pierwszych miesiącach po zakończeniu działań wojennych szkoły przyjęły tylko niewielką liczbę młodzieży. W roku szkolnym 1944/45, który trwał od maja do sierpnia 1945 r., we wszystkich szkołach naukę podjęło 3612 uczniów ${ }^{29}$. Wraz z rozwojem sieci szkolnej i nasileniem się ruchów migracyjnych, młodzieży w szkole przybywało. Już w następnym roku szkolnym jej liczba przekroczyła 10 tys. ${ }^{30}$ Rozwój ilościowy młodzieży uczącej się w średnich szkołach ogólnokształcących w latach 1945-1948 ilustruje tabela 2.

27 APG, KOSG 1945-1991, sygn. 1178/130, Formularze sprawozdawczo-statystyczne za rok szkolny 1945/46, k. 3-155.

28 Rocznik Statystyczny 1947, Warszawa 1947, s. 161.

29 APG, KW PPR, sygn. 2259/41, Rozwój szkolnictwa w okręgu gdańskim, k. 17.

30 Ibidem, sygn. 2259/41, Wykaz obrazujący wzrost ilości szkół, nauczycieli młodzieży uczącej się za czas od 1.05.1945 r. do 1.051946 r., k. 56. 
Tabela 2. Młodzież uczęszczająca do liceów i gimnazjów ogólnokształcących w województwie gdańskim w latach 1945-1948

\begin{tabular}{|c|c|c|c|}
\hline Rok szkolny & Liczba placówek & Liczba uczniów & Uwagi \\
\hline $1944 / 1945$ & 14 & 3612 & stan na dzień 1.08.1945 r. \\
\hline $1945 / 1946$ & 28 & 10449 & stan na dzień 1.III.1946 r. \\
\hline $1946 / 1947$ & 25 & 10075 & stan na dzień 1.02.1947 r. \\
\hline $1947 / 1948$ & 25 & 8540 & $\begin{array}{c}\text { bez młodzieży uczącej się } \\
\text { w ciągach skróconych }\end{array}$ \\
\hline
\end{tabular}

Źródło: APG, KW PPR, sygn. 2598/41, Rozwój szkolnictwa w okręgu gdańskim, k. 17; ibidem, Wykaz obrazujący wzrost ilości szkół, nauczycieli młodzieży uczącej się za czas od 1.05.1945 r. do 1.051946 r., k. 56; ibidem, Wykaz KOS Gdańskiego, k. 62; E. Jarecki, Licea ogólnoksztatcace $w$ województwie gdańskim przed reforma, Gdańsk 1968, s. 32.

W badanym okresie niezwykle ważkim problemem było też pozyskanie kadry pedagogicznej do pracy w uruchamianych placówkach. Jednym z najbardziej palących problemów ówczesnych władz oświatowych stało się zapewnienie dopływu kadr pedagogicznych do szkół wszystkich szczebli. Niedobór nauczycieli odczuwało szkolnictwo na terenie całego kraju, szczególnie zaznaczył się on jednak na Ziemiach Zachodnich i Północnych. Taka sytuacja miała miejsce również $\mathrm{w}$ województwie gdańskim. Z powodu wielkich niedostatków kadrowych z niecierpliwością czekano na tych terenach na przybycie nauczycieli z innych stron kraju. Pierwsi dotarli tu nauczyciele z województw ościennych i z Polski centralnej. W powiatach nowych stanowili oni najliczniejszą grupę, która na ten teren przybywała wraz z kolejnymi falami osadników ${ }^{31}$. Jednakże, jak czytamy w sprawozdaniu z akcji osiedleńczej, w miesiącu lipcu i pierwszej połowie sierpnia 1945 r. w prawie stutysięcznej grupie przesiedleńców i repatriantów było zaledwie 34 nauczycieli ${ }^{32}$. Dopiero wraz z kolejnymi transportami ich liczba zaczęła wzrastać.

Analizując sytuację kadrową szkolnictwa ogólnokształcącego w województwie gdańskim, można zauważyć, że w całym badanym okresie borykało się ono z trudnościami kadrowymi. W związku ze stałym brakiem nauczycieli do pracy w szkołach przyjmowano osoby niemające odpowiednich kwalifikacji zawodowych. Warto dodać, że od kandydatów na nauczycieli szkół średnich wymagano wówczas wykształcenia na poziomie studiów wyższych i posiadania przygotowania pedagogicznego. Przewidywano jednak możliwość zatrudnienia osób niemających takich kwalifikacji ${ }^{33}$. Tak też w roku szkolnym

31 B. Potyrała, W. Szlufik, op. cit., s. 301 i 304.

32 APG, UWG 1945-1954, sygn. 1164/354, Sprawozdanie miesięczne referatu akcji osiedleńczej za miesiąc lipiec 1945 r., k. 16-18.

${ }^{33}$ Kwalifikacje zawodowe nauczycieli szkół średnich ogólnokształcących i seminariów nauczycielskich, obok pragmatyki z 1926 r., określała ustawa z 1922 roku oraz Ustawa z 11 marca 1932 r. Zawarty w nich był 
1945/46 w szkolnictwie średnim ogólnokształcącym województwa gdańskiego na zatrudnionych 240 nauczycieli 84 nie posiadało odpowiednich kwalifikacji do pracy w tego typu szkole. Stanowili oni 35\% zatrudnionej kadry. W latach następnych sytuacja tylko nieznacznie się poprawiła, bowiem w gimnazjach i liceach zatrudniano wówczas prawie 30 \% nauczycieli niekwalifikowanych. Należy dodać, że zarówno w powiatach dawnych, jak i nowych nie zaznaczały się wyraźne różnice związane z poziomem wykształcenia nauczycieli szkół tego szczebla ${ }^{34}$. Stan i kwalifikacje kadry nauczycielskiej średnich szkół ogólnokształcących w latach 1945-1948 ilustruje tabela 3.

Tabela 3. Kadra nauczycielska szkół średnich ogólnokształcących województwa gdańskiego w latach 1945-1948

\begin{tabular}{|c|c|c|c|}
\hline Rok szkolny & $\begin{array}{c}\text { Liczba zatrudnionych } \\
\text { nauczycieli }\end{array}$ & $\begin{array}{c}\text { Liczba nauczycieli } \\
\text { posiadających } \\
\text { kwalifikacje zawodowe }\end{array}$ & $\begin{array}{c}\text { Liczba nauczycieli bez } \\
\text { kwalifikacji zawodo- } \\
\text { wych }\end{array}$ \\
\hline $1944 / 1945$ & 142 & bd d & 84 \\
\hline $1945 / 1946$ & 244 & 160 & 128 \\
\hline $1946 / 1947$ & 438 & 310 & 126 \\
\hline $1947 / 1948$ & 437 & 311 & 84 \\
\hline
\end{tabular}

Źródło: APG, KW PPR, sygn. 2598/41, Wykaz obrazujący wzrost ilości szkół, nauczycieli młodzieży uczącej się za czas od 1.05.1945 r. do 1.05.1946 r. k.56; AP KOSG 1945-1990, sygn. 1178/134, Nauczyciele zatrudnieni w szkołach średnich ogólnokształcących KOS Gdańskiego, stan na 1.10.1946 r., k. 112; ibidem, Nauczyciele zatrudnieni w szkołach średnich ogólnokształcących KOS Gdańskiego, stan na 30.09. 1947 r. k. 118; Szkolnictwo w liczbach 1945/46, Warszawa 1946, s. 27.

wymóg ukończenia studiów wyższych oraz zdania egzaminu na nauczyciela szkoły średniej. Do rozwiązań z okresu międzywojennego nawiązywał też dekret o organizacji szkolnictwa w okresie przejściowym z dn. 22. 11.1945 r., który określił, że kandydaci na nauczycieli szkół średnich powinni kształcić się w szkołach wyższych, po których ukończeniu obowiązani byli do odbycia co najmniej rocznego kształcenia na kierunku pedagogicznym lub złożenia egzaminu na nauczyciela szkoły średniej. Dekret stworzył również możliwość powoływania w okresie przejściowym, nie dłuższym jednak niż 6 lat, na stanowiska nauczycieli osób nieposiadających kwalifikacji zawodowych do pracy pedagogicznej. Ponadto w 1946 r. uznano, że kwalifikacje do nauczania w szkołach średnich posiadają też osoby, które: 1) uzyskały stopień magistra, względnie ukończyły inne równorzędne studia wyższe oraz odbyły co najmniej 2-letnią praktykę nauczycielską, 2) uzyskały przed 1 września 1939 r. stopień magistra (względnie inny równorzędny dyplom) i zostały dopuszczone do egzaminu państwowego na nauczyciela szkół średnich, ale nie zdały go w okresie wojny oraz mają roczną praktykę pedagogiczną.

34 Szkolnictwo w liczbach 1945/46, Warszawa 1946, s. 27; APG, KOSG 1945-1990, sygn. 1178/134, Nauczyciele zatrudnieni w szkołach średnich ogólnokształcących KOS Gdańskiego, stan na 1.10.1946 r., k. 112; tamże, Nauczyciele zatrudnieni w szkołach średnich ogólnokształcących KOS Gdańskiego, stan na 30.09. 1947 r. Obliczenia autorki. 
Taki stan kadry pedagogicznej spowodowany był nie tylko niedostatecznym dopływem nauczycieli z odpowiednim wykształceniem, ale i dużym ich odpływem z zawodu, którego przyczyną była m.in. możliwość podjęcia pracy w różnych gałęziach gospodarki. Przed ludźmi z wykształceniem - jako specjalistami - otwierały się atrakcyjne perspektywy pracy, za którą otrzymywali zdecydowanie wyższe wynagrodzenie niż w szkole. Potwierdzają to sprawozdania starostów, inspektorów, czy dyrektorów szkół. Na przykład we wrześniu 1946 r. starosta powiatowy w Lęborku, Jan Piotrowski, w swoim sprawozdaniu sytuacyjnym zapisał: Niedostateczne uposażenie nauczycieli powoduje odptyw sit nauczycielskich na inne stanowiska lepiej płatne ${ }^{35}$.

Radykalne zmiany w rozwoju szkolnictwa średniego ogólnokształcącego przyniósł rok 1948. Na mocy Instrukcji w sprawie organizacji roku szkolnego 1948/49 w szkolnictwie ogólnokształcącym ${ }^{36}$ władze rozpoczęły budowę jednolitej szkoły ogólnokształcącej stopnia podstawowego i licealnego. Działania te uzasadniano koniecznością szybkiego przygotowania wykwalifikowanych kadr robotniczych dla gospodarki i przemysłu. W wyniku przeprowadzonych zmian dotychczasowe gimnazja i licea ogólnokształcące po połączeniu ze szkołami podstawowymi uległy przekształceniu w jednolite szkoły stopnia podstawowego i licealnego lub zostały przemianowane na szkoły ogólnokształcące stopnia licealnego ${ }^{37}$. W wyniku tych przemian w województwie gdańskim dokonano reorganizacji sieci szkolnej, w wyniku której powołano 36 liceów ogólnokształcących ${ }^{38}$.

Podsumowując ten krótki okres działalności gimnazjów i liceów ogólnokształcących w województwie gdańskim, należy zaznaczyć, że ich rozwój przebiegał w niezwykle trudnych warunkach. Cechowały je ogromne spustoszenie materialne i kulturowe, wyludnienie, brak zaplecza ekonomicznego oraz wszechobecne poczucie tymczasowości. Kształtowała natomiast polityka PPR i centralnych władz oświatowych wskazująca wyraźnie miejsce tego typu szkół w systemie oświatowym. Analizując działalność placówek tego szczebla edukacji, obserwujemy pewne różnice w ich organizacji występujące między powiatami dawnymi a nowymi. W powiatach nowych szkoły tworzone były od podstaw, a ich początki datują się na rok szkolny 1945/46. Zaś w powiatach dawnych większość szkół opierała swoją działalność o przedwojenne zaplecze i tradycje, a pracę dydaktyczną rozpoczynała praktycznie po zakończeniu działań wojennych. Obserwujemy również, że funkcjonowanie średnich szkół ogólnokształcących tworzyło korzystną koniunkturę dla osadnictwa. Dotyczyło to szczególnie powiatów dawnych, w których uruchomienie szkoły odbierane było jako czynnik dający napływającej ludności pewne poczucie stabilizacji.

${ }^{35}$ APG, UWG 1945-1954, sygn. 1164/84, Sprawozdanie sytuacyjne Starosty Powiatowego Lęborskiego za miesiąc wrzesień 1946 r.

${ }^{36}$ Dz. Urz. Min. Oświaty nr 5 z 4 maja 1948 r. poz. 86.

37 L. Szuba, op. cit., s. 157.

${ }^{38}$ E. Jarecki, op. cit., s. 40. 
